\title{
Macénites : Note linguistique complémentaire
}

\section{S. Chaker}

\section{OpenEdition}

\author{
Journals
}

Édition électronique

URL : http://journals.openedition.org/encyclopedieberbere/385

DOI : 10.4000/encyclopedieberbere.385

ISSN : 2262-7197

\section{Éditeur}

Peeters Publishers

\section{Édition imprimée}

Date de publication : 29 décembre 2010

Pagination : 4459-4460

ISBN : 978-90-429-2367-6

ISSN : 1015-7344

\section{Référence électronique}

S. Chaker, « Macénites : Note linguistique complémentaire », Encyclopédie berbère [En ligne], 30 | 2010, document M05b, mis en ligne le 17 septembre 2020, consulté le 15 octobre 2020. URL : http://

journals.openedition.org/encyclopedieberbere/385 ; DOI : https://doi.org/10.4000/ encyclopedieberbere.385

Ce document a été généré automatiquement le 15 octobre 2020

(c) Tous droits réservés 


\section{Macénites : Note linguistique complémentaire}

\section{S. Chaker}

1 Le rapprochement, "classique» chez les historiens, entre les Macenites (peuple de l'Antiquité) et les Miknasa (peuple du Moyen Âge; la forme berbère devait être *Imeknasen) n'est pas recevable du point de vue de la linguistique berbère et doit être définitivement abandonné.

2 On a d'un côté un thème nominal Maken-, de l'autre Miknas/Meknas, sans qu'il soit possible de voir un quelconque "suffixe" dans le /-s/ final. Le berbère (ni l'arabe d'ailleurs) ne connaît pas un tel suffixe; $s$ - n'existe dans la morphologie berbère qu'en tant que préfixe (verbal et nominal). Si le thème Miknas/Meknas doit être décomposé, ce ne peut être qu'en $M+K N S$, avec un préfixe $M$ - de nom d'agent sur une racine KNS, parfaitement attestée en berbère contemporain, "se disputer, se quereller ». Le /s/ final est donc nécessairement radical, ce qui rend hautement improbable tout rapprochement avec les Macenites.

INDEX

Mots-clés : Antiquité, linguistique 